\title{
Energy storage in underground coal mines in NW Spain: Assessment of an underground lower water reservoir and preliminary energy
} \section{balance}

\author{
Javier Menéndez $^{\mathrm{a},}{ }^{*}$, Jorge Loredo ${ }^{\mathrm{b}}$, Mónica Galdo ${ }^{\mathrm{c}}$, Jesús M. Fernández-Oro ${ }^{\mathrm{c}}$ \\ ${ }^{a}$ Hunaser Energy, Avda. Galicia, 44, 33005, Oviedo, Spain \\ ${ }^{\mathrm{b}}$ Mining Exploitation Department, University of Oviedo, Independencia 13, 33004, Oviedo, Spain \\ ${ }^{c}$ Energy Department, University of Oviedo, Departmental Building East Zone, Campus of Viesques, 33271, Gijón, Spain
}

\section{A R T I C L E I N F O}

\section{Article history:}

Received 14 May 2018

Received in revised form 29 August 2018

Accepted 15 September 2018

Available online 20 September 2018

\section{Keywords:}

Pumped storage

Energy storage

Hydropower

Coal mining

Underground water reservoir

\begin{abstract}
A B S T R A C T
During the last decades, the Asturian Central Coal Basin (ACCB) has been a highly exploited coal mining area by means of underground mining and its network of tunnels extend among more than 30 mines. Parts of this infrastructure will soon become available for alternative uses since most of the coal mining facilities in Spain will fade out in 2018. Increasing penetration of renewable energy sources into the electrical grid, with intermittent and fluctuating supply, leads to excessive frequency variations, so the development of energy storage technologies are required, such as Pumped Storage Hydroelectricity (PSH). Reduced environmental impacts, deep, non-flooded shafts and abundance of water from underground run-off, make coal mines in ACCB suitable for the development of Underground Pumped-Storage Hydropower projects (UPSH). The network of tunnels of a mine facility has an unusual geometry for a water storage system. Although there are numerous studies for the construction of UPSH plants, until now there have been no known projects of this type under operation. Filling and emptying processes during the operation of the turbine-pump are complex due to the presence of two fluids interacting inside the tunnels, water and air. This paper explores the viability of a network of tunnels as an underground water reservoir. Two-phase three-dimensional CFD models have been developed in order to know the flow behavior in the tunnels. The pressure and velocity results that have been obtained in the simulations confirm that the use of underground mines as a lower reservoir of a UPSH is technically possible.
\end{abstract}

(c) 2018 Elsevier Ltd. All rights reserved.

\section{Introduction}

In 2015, the world total primary energy supply was 13,647 Mtoe, of which 13.4 Mtoe was from renewable energy sources. Since 1990, renewable electricity generation worldwide grew on average by $3.6 \%$ per annum, which is slightly faster than the total electricity generation growth rate (2.9\%) [1]. So, whilst $19.4 \%$ of the global electricity in 1990 was produced from renewable sources, this share has increased to $22.8 \%$ in 2015. In the Organization for Economic Cooperation and Development (OECD), gross electricity production from renewable products reached 2588.3 TWh in 2016 [1]. This represents $23.8 \%$ of total OECD electricity production in 2016.

\footnotetext{
* Corresponding author.

E-mail address: jmenendezr@hunaser-energia.es (J. Menéndez).
}

The European energy and climate policies have, as one of their targets, a $20 \%$ of final energy from renewable origin by 2020 [2]. The EU's 2050 decarbonization objectives, with a target of $80-95 \%$ reduction in greenhouse gas emissions (GHE) compared to 1990 levels [3], will require a significantly higher share of renewables in the electricity mix, possibly between 90 and $100 \%$. It will be necessary to reduce the share of fossil fuels and to install between 145 and $200 \mathrm{GW}$ of renewable energy, and a high component of this will be non-dispatchable energy sources, such as wind and solar.

The most important concern with respect to some forms of renewable energy, such as solar and wind energies, is their intermittence and fluctuating supply which leads to frequency variations. The production of these energy sources cannot be matched to variations in demand [4-6]. Energy storage systems are then required to deal with this intermittency as they provide flexibility by shifting the load demand temporally [7,8]. Energy storage 
systems allow the production of electricity to be managed according to the demand [9]. These systems allow the excess energy to be stored during low demand periods and to produce electricity when the demand increases.

Pumped-storage is an old and known mature technology for large-scale storage of electricity [10]. Historically, it has been used to balance load on a system, enabling large nuclear or thermal generating sources to operate at peak efficiencies. PSH store electricity by moving water between an upper and lower reservoir. Electric energy is converted to potential energy and stored in the form of water at an upper elevation. Currently, PSH is one of the most used storage systems because it allows the generation and consumption of large amounts of energy for a short period of time [11], representing $99 \%$ of on-grid electricity storage.

According to the U.S. Energy Information Administration (EIA), as of 2014, pumped-storage systems accounted for approximately $150 \mathrm{GW}$ world-wide. The leading countries in pumped-storage are: Japan (27 GW), United States (22 GW), China (21 GW) and over $40 \mathrm{GW}$ in Europe [12]. The International Renewable Energy Agency (IRENA) conducted a technology roadmap until 2030, and the pumped hydro capacity could be doubled to $325 \mathrm{GW}$ [13].

Underground Pumped Storage Hydropower plants (UPSH) is an alternative to store and manage large amounts of electricity that is not limited by impacts on landscape, environment and society [14,15]. UPSH plants consist of two reservoirs; the upper reservoir is located at the surface, in an area of industrial land belonging to the coal mining, while the lower reservoir is underground. The alternatives for the lower reservoir are: (1) to excavate and secure additional caverns; (2) to make use of existing drifts; or (3) to dig new tunnels $[16,17]$. Although abandoned mining works could be used as an underground reservoir, the most technically feasible alternative would be the drilling of a new network of tunnels [18]. Impacts on land use, vegetation and wildlife produced by UPSH are lower than those of PSH because one of the reservoirs is underground. However, it is needed to consider the effects of UPSH plants on surrounding porous media to quantify the total environmental impact [19].

From the socio-economic point of view, the reuse of mines for the construction of UPSH contributes to the creation of new economic activities and to the generation of employment in depressed mining regions due to the closure of the mines. In addition, the flooding of the mines is not carried out, so the mining reserves remain accessible.

Some studies have considered the use of underground reservoirs, however until now there have been no known projects of this type under operation. The first UPSH scheme was proposed in 1901 by Reginald A. Fessenden, who envisaged - with amazing foresight storing "natural intermittent sources of power, such as solar radiation and wind power" [20]. As early as 1960s, Richard D. Harza had suggested the idea to use an abandoned mine as underground lower reservoir and build a hydro pumped storage plant [21].

At the end of the 1960s, Swedish engineers had proposed the exploitation of a surface reservoir and the construction of a new lower artificial reservoir in an underground cavity, with a cross section of $200 \mathrm{~m}^{2}$ at a depth of $450 \mathrm{~m}$ below the ground level [22]. In 1969, Sorensen had suggested an optimistic future for the development of underground pumping stations [23]. The Mount Hope project, located in northern New Jersey was initially proposed in 1975 [24]. It intended to use the facilities of an abandoned iron mine as a lower reservoir, but it was never developed. In 1978, an UPSH project was presented, with a lower reservoir conformed by a grid of $15 \times 25 \mathrm{~m}$ elliptical tunnels, to a depth of $1000 \mathrm{~m}$ [25].

During the 1980 s, a project to install an UPSH plant was launched in the Netherlands [26], but the plant was not finally constructed for different reasons such as the inadequate characteristics of the soil. In 1996, Wong assessed the possibility of constructing UPSH plants in Singapore using abandoned rock quarries as upper reservoirs [15]. In this case, Wong proposed to drill tunnels or shafts to be used as underground reservoirs. Recently, some preliminary studies have been also carried out in Germany to assess the possibilities for constructing UPSH plants on abandoned coal mines in the Harz and Ruhr regions [27-29]. Lately, a replicable methodology has been proposed and applied to the Italian territory to calculate the underground pumped hydro storage potential [30].

\section{Materials and methods}

\subsection{Study area}

The ACCB is located in Asturias (NW Spain). During the last decades it has been an exploited coal mining area by means of underground mining. During this time, ACCB mines produced more than $50 \%$ of all of Spain's domestic coal, the basic energy source at that time. It was one of the most important economic activities in Asturias and an outstanding source of employment creation, which therefore contributed to the current development of the surrounding towns. However, since the late 1980s, most of Asturias' mine shafts have closed or are closing with a definitive cessation date of extractive activity at the end of 2018 [31].

Underground coal mines have a typical depth of up to $500-600 \mathrm{~m}$, with a main infrastructure composed of several vertical shafts with a diameter of 5-6 m, used for mineral extraction and for access of personnel and materials. It has an extensive network of horizontal tunnels at different levels, with an average separation between levels of $80-100 \mathrm{~m}$. An average of $40 \mathrm{Mm}^{3}$ year $^{-1}$ of underground run-off water is pumped from the deepest level of the mines.

When mining ends, one option is to abandon pumping, gradually flooding both the mine voids and the open pores; this 'groundwater rebound' [32,33] continues until potentiometric equilibrium is reached [34]. If the lithological units connected to any part of the flooded system intersect the surface at a level lower than that of the mouth of the mine shaft, water upwelling will occur.

\subsection{UPSH design and preliminary energy balance}

UPSH uses an upper reservoir which provides water storage capacity at ground level, and a lower reservoir excavated in rock at a depth using an underground coal mine to give a suitable head. The upper reservoir is located in the current mining facilities, in an area of industrial land where it is viable from the legal point of view. The upper reservoir can also be constructed underground [35], but this would imply a significant increase of investment costs. The power house itself, accommodating appropriate Francis turbine-pump units and associated plant, is also underground. Because the lower reservoir is located underground, it can be placed directly under the upper reservoir, in a location that minimizes the horizontal distance between the two reservoirs, and hence, the length of the penstock. Penstock would be installed in the existing vertical shafts of coal mines with a typical diameter about $3 \mathrm{~m}$ for UPSH plants. Existing shafts would be used also for ventilation and to carry power conductors to the energy grid. Due to the dimensions and capacity of the current vertical shafts, it would be necessary to build a new access tunnel from the outside to the powerhouse cavern. This access would be used for the construction phase (hydropower and electrical equipment transport) and operation and maintenance phase. The cross section would be $22 \mathrm{~m}^{2}$ and the slope of the tunnel would be between 10 and 12\% descending. An UPSH 
scheme differs from a conventional PSH scheme in the location of the lower reservoir for the underground storage. The lower reservoir could take the form of series of excavations located at a higher level than the turbine-pump to maintain minimum submergence of the pump-turbine runners in all conditions. Hence, a new network of tunnels reinforced with concrete, with a cross section of $30 \mathrm{~m}^{2}$ and a length of $200 \mathrm{~m}$, has been designed. To minimize the surface area occupied, the reservoir design has a central tunnel, from which transversal tunnels depart on both sides with a distance between them of $20 \mathrm{~m}$. Transversal tunnels have a slope of $2 \%$ to the central tunnel. The cavern of the powerhouse would be excavated from top to bottom. The dimensions of the underground cavern would be $30 \mathrm{~m}$ long, $15 \mathrm{~m}$ wide and $40 \mathrm{~m}$ high. Transformers hall would have a dimensions of $20 \mathrm{~m}$ long, $8 \mathrm{~m}$ wide and $10 \mathrm{~m}$ high. To absorb sudden rises of pressure (water hammer) and provide extra water during a brief drop in pressure, fundamentally in the pumping phase, a surge tank would be built between the lower reservoir and the powerhouse. The cross section of the surge tank would be $12.57 \mathrm{~m}^{2}$ (4 m diameter), and it would have a height of $80 \mathrm{~m}$. The scheme of the UPSH for the designed project is shown in Fig. 1.

A competent rock mass is a necessary requirement for an underground placement of the lower reservoir and the powerhouse. Information about mechanical properties of the rock in the project location is extensive, due to the knowledge acquired after the last decades of mining activity. The data available suggest that conditions are suitable for the construction of all the necessary underground infrastructure. Lower reservoir, power house and transformers hall are to be constructed by drill and blast methods. The surge tank would be drilled using the raise boring method.

One of the most outstanding singularities of a UPSH project is the geometric form of the lower reservoir. Before the lower reservoir starts to be filled with water during the turbine mode operation, the tunnels are completely filled with air. In order to carry out an adequate operation of the turbine, it is necessary to evacuate the air existing in the tunnels during the whole process. This implies
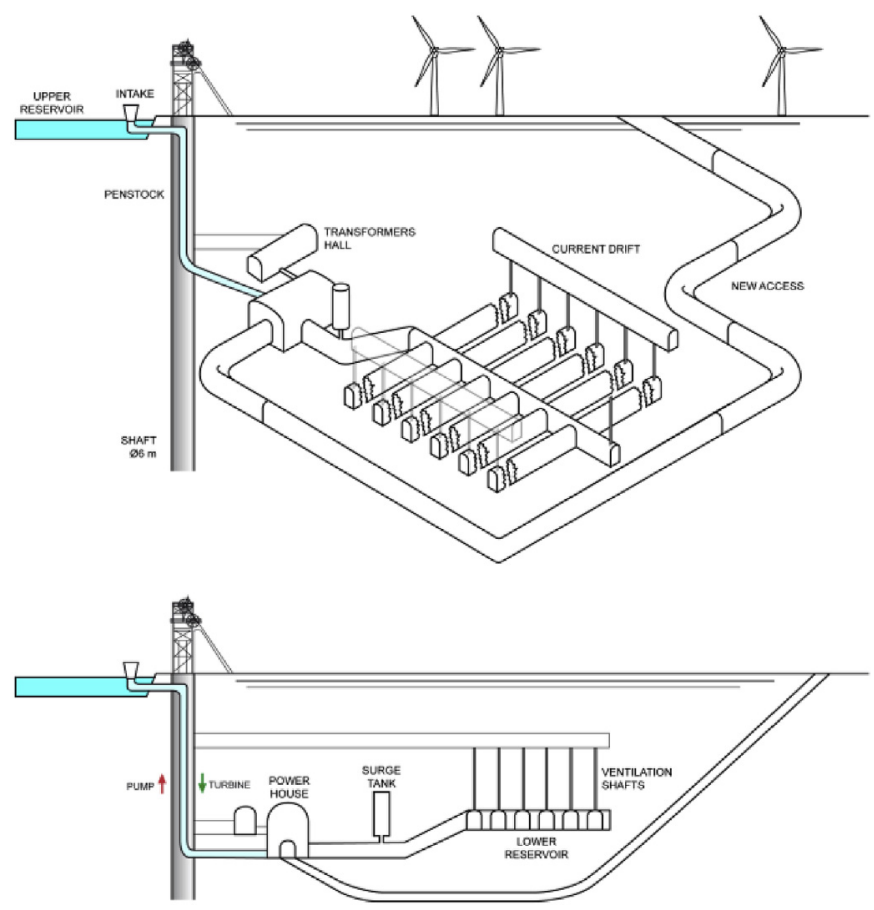

Fig. 1. UPSH design. Main elements of an UPSH project in the facilities of an underground coal mine: Reservoirs, penstock, powerhouse, transformers hall, ventilation shafts and surge tank. that it is necessary to excavate ventilation shafts in each of the tunnels. Otherwise, the resistance offered by the air, which is compressed as the volume of the tunnels is filled with water, would suppose a major problem in the discharge of the turbine towards the underground reservoir. Thus, ventilation shafts can be connected to abandoned works, and even be drilled using the raise boring method. The storable amount of energy depends on the head and the water mass available. Table 1 reports the resulting capacity on selected possible heads as a function of different amounts of water, for typical hydro-turbo efficiencies.

The power of the turbine depends on the operating time at full load. UPSH plants can be configured for different operating times, depending on the storage volumes and the water turbine output. The operation time at full load here is the time period when the turbine works at full capacity, until the entire available hydro storage capacity is depleted. In the long term, a dimensioning to shorten charging and discharging times seems likely. Therefore, in the considerations that follow, dimensioning for $4 \mathrm{~h}$ of operation will be assumed. Fig. 2 shows the power of the turbine for different heads and water masses, with an operating time at full load of $4 \mathrm{~h}$.

Table 2 shows the nominal parameters selected for the projects. The power in turbine mode is $116.21 \mathrm{MW}$. The annual power generation of the facility would be $169.66 \mathrm{GWh}_{\text {year }}{ }^{-1}$. Considering all the active mining operations of the ACCB, a total net power of $1 \mathrm{GW}$ could be reached. It is a very important power figure that could contribute in the ancillary services of the electrical system in a significant way.

\subsection{Numerical model}

In order to know the behavior of the flow inside the lower reservoir, a couple of two-phase CFD three-dimensional models have been created. Fig. 4 shows the design of the underground reservoirs that will be studied. In both reservoirs $100 \%$ filling efficiencies are achieved. Both models are similar, with small geometric variations. In model A, each transversal tunnel has a slope of $2 \%$ and a ventilation shaft, while in model B the transversal tunnels are horizontal, and all the air comes out through a single ventilation shaft with a larger section, located in the central tunnel. The geometrical characteristics of the models A and B shown in Fig. 3 are summarized in Table 3 and Table 4 respectively.

The simulations were performed with the commercial CFD software Ansys Fluent V16.0, solving the Unsteady Reynolds-Averaged Navier-Stokes (URANS) equations with a twophase scheme. This numerical model is developed meshing the geometry into different small cells in which the flow equations must be solved. The application of boundary conditions and the resolution of the discretized equations provides the final solution of the model. A three-dimensional structured mesh has been developed for the entire domain, employing tetrahedral and hexahedral cells because of their suitable adaptation to the geometry. The mesh used for the calculations reaches up to about $4.9 \cdot$ million cells for

Table 1

Storage capacity (storable amount of energy) of a UPSH plant [in MWh] for different heads and water masses. Computations account for a turbine efficiency of $90 \%$, alternator efficiency $98,5 \%$ and transformer efficiency $99 \%$.

\begin{tabular}{llllll}
\hline Net Head [m] & \multicolumn{5}{l}{ Water Mass [Mt] } \\
& 0.2 & 0.3 & 0.4 & 0.5 & 0.6 \\
100 & 47.83 & 71.75 & 95.66 & 119.58 & 143.49 \\
200 & 95.66 & 143.49 & 191.32 & 239.16 & 286.99 \\
300 & 143.49 & 215.24 & 286.99 & 358.73 & 430.48 \\
400 & 191.32 & 286.99 & 382.65 & 478.31 & 573.97 \\
500 & 239.16 & 358.73 & 478.31 & 597.89 & 717.47 \\
600 & 286.99 & 430.48 & 573.97 & 717.47 & 860.96 \\
\hline
\end{tabular}




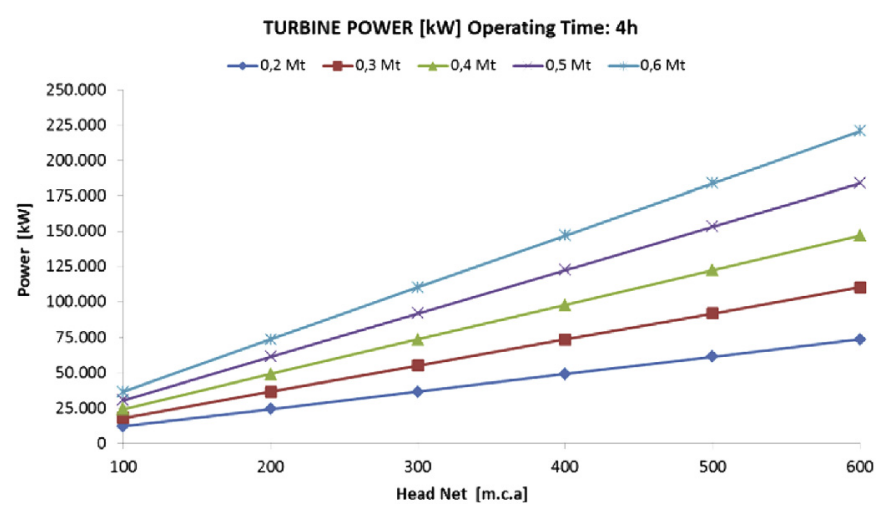

Fig. 2. Power of the turbine for different heads and water masses. Operating time of $4 \mathrm{~h}$ at full load and turbine efficiency of $90 \%$.

model A and $4.5 \cdot$ million cells for model B.

The Volume Of Fluid (VOF) approach has been selected for the two-phase (water and air) modelling. Its formulation is designed for two or more immiscible fluids where the position of the interface between the fluids is of interest [36]. Variables and properties (density, viscosity, etc.) of each phase are volume-averaged values, calculated using a volume fraction ratio of each phase for every cell. The model includes continuity equations for each phase and the URANS momentum equation for the entire domain. Those equations allow describing each fluid movement as well as tracking the water-air interface (considering both as incompressible flows). For interpolation near the interface, a piecewise-linear scheme is used
[37]. To solve the equations during the water filling process of the underground reservoir, a set of boundary conditions were selected. In the case of the air outlet in the ventilation shafts, a stable pressure value corresponding to the standard atmospheric pressure (101,325 Pa) was set. In order to know the real value of the velocity and the pressure in the shafts, the boundary condition does not apply directly at the outlet of the shafts. Large ventilation rooms have been implemented where the atmospheric pressure was set, away from the air outlet. Furthermore, for the water inlet in the tunnels, a velocity of $1 \mathrm{~m} / \mathrm{s}$ was considered, to obtain a flow rate of $30 \mathrm{~m}^{3} / \mathrm{s}$, according to the design flow of the UPSH project (Table 2). In the two-phase model, air and water were considered to have constant densities and dynamic viscosities. The values used were a density of $1.225 \mathrm{~kg} / \mathrm{m}^{3}$ and a dynamic viscosity of $1.789 \cdot 10^{-5} \mathrm{~kg} / \mathrm{m}$ $\mathrm{s}$ for the air; a density of $998 \mathrm{~kg} / \mathrm{m}^{3}$ and dynamic viscosity of $1.003 \cdot 10^{-3} \mathrm{~kg} / \mathrm{m} \mathrm{s}$ for the water. Note that all the galleries and tunnels are connected to outside atmospheric conditions, so airflows will be driven with reduced pressure gradients associated to the required friction losses. In addition, although thermal differences in the air may arise due to lower temperatures in the deepest tunnels, buoyancy effects are not especially relevant for this investigation, so they have been considered marginal with respect to the displacing effect of the incoming water into the galleries. Consequently, the air phase has been considered as incompressible and the ideal-gas assumption has not been modelled in the present numerical database.

To resolve the coupling between pressure and velocity fields in the Navier-Stokes equations, the transient form of the PressureImplicit with Splitting of Operators (PISO) algorithm was used. In this specific case, as the flow is incompressible and the energy

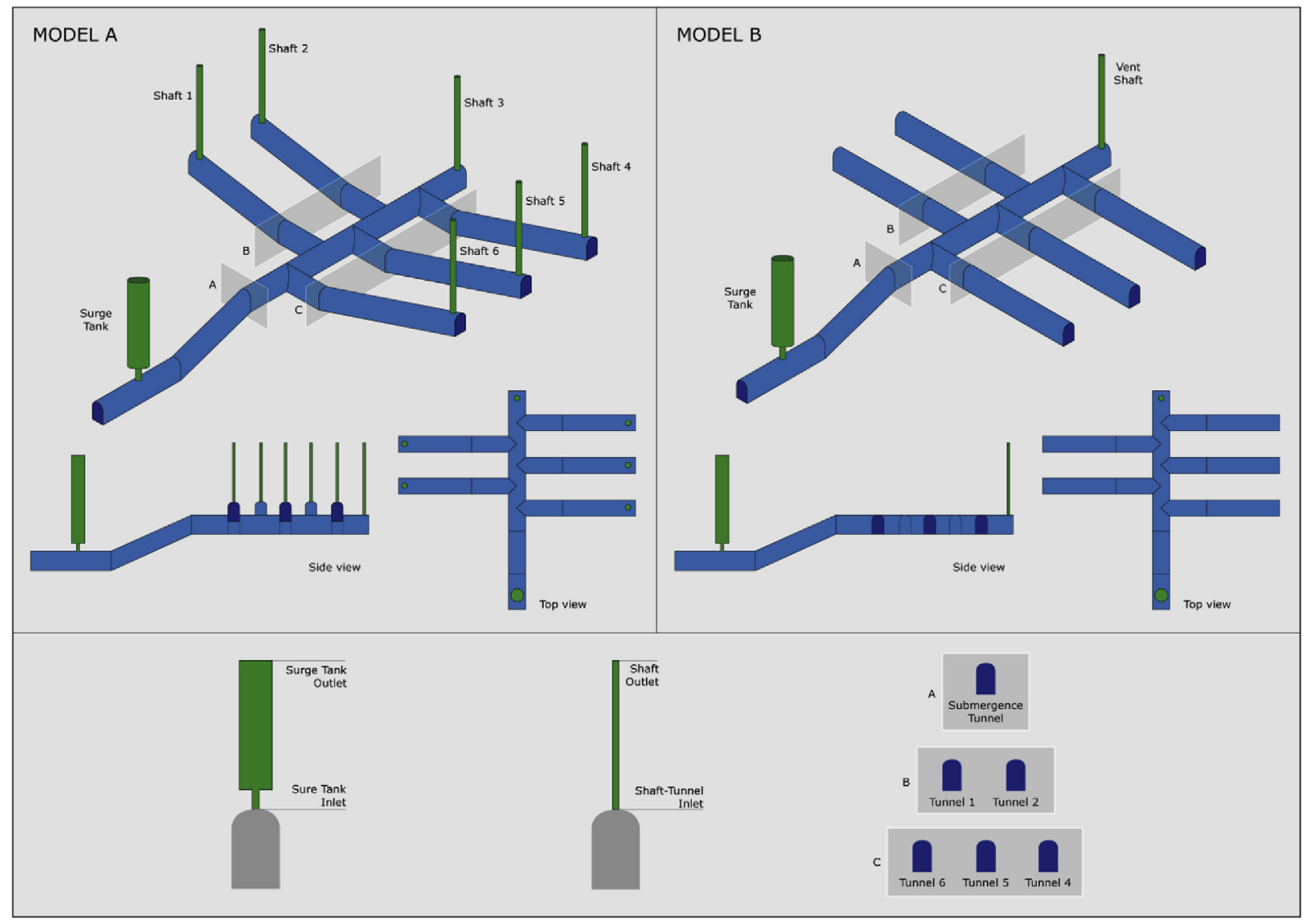

Fig. 3. Three-dimensional CFD models. Geometry of the numeric models of underground lower storage. 
Table 2

Main characteristics of the UPSH project with a Francis Turbine. Power in turbine and pump mode, and annual energy storage capacity.

\begin{tabular}{ll}
\hline UPSH Design & \\
\hline Lower reservoir $\left(\mathrm{m}^{3}\right)$ & 450,000 \\
Lower reservoir tunnels network $(\mathrm{m})$ & 15,000 \\
Operating time full load $(\mathrm{h})$ & 4.00 \\
Gross head $(\mathrm{m})$ & 450.00 \\
Net head $(\mathrm{m})$ & 438.75 \\
Penstock diameter $(\mathrm{m})$ & 3.00 \\
Flow $\left(\mathrm{m}^{3} / \mathrm{s}\right)$ & 30.00 \\
Flow velocity $(\mathrm{m} / \mathrm{s})$ & 4.24 \\
Turbine efficiency $(\%)$ & 90.00 \\
Pump efficiency $(\%)$ & 80.00 \\
Turbine power $(\mathrm{MW})$ & 116.21 \\
Pump power $(\mathrm{MW})$ & 92.97 \\
Energy storage $(\mathrm{GWh} /$ year $)$ & 169.66 \\
\hline
\end{tabular}

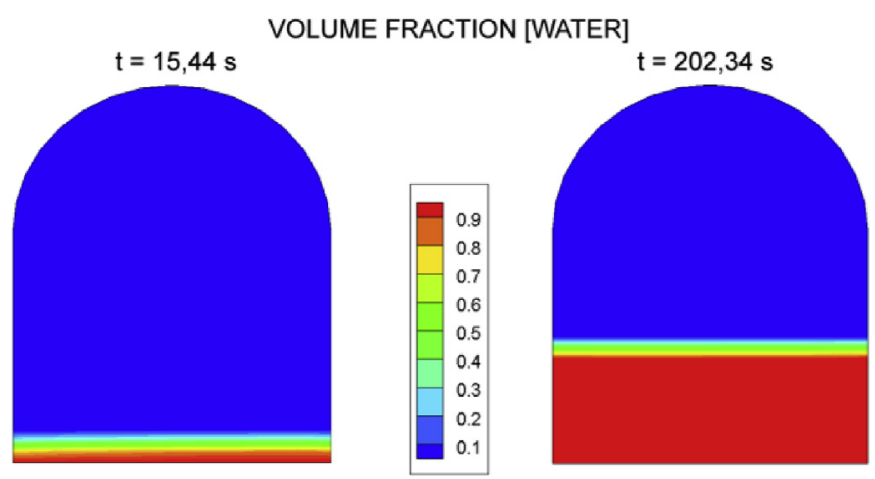

Fig. 4. Volume fraction in tunnels $t=5.43 \mathrm{~s}$ and $\mathrm{t}=202.34 \mathrm{~s}$.

Table 3

Geometric model A of underground lower water storage in the shape of tunnels.

\begin{tabular}{llll}
\hline \multicolumn{3}{l}{ GEOMETRIC MODEL A UNDERGROUND LOWER RESERVOIR } \\
\hline TUNNELS NETWORK & & \\
\hline Tunnels & Cross Section $\left(\mathrm{m}^{2}\right)$ & Length $(\mathrm{m})$ & Slope $(\%)$ \\
\hline Central Tunnel & 30 & 94 & 0 \\
Transversal Tunnels & 30 & 200 & 2 \\
Submergence Tunnel & 30 & 200 & 10 \\
VENTILATION SHAFTS AND SURGE TANK & & \\
\hline Shafts & Diameter $(\mathrm{m})$ & Length $(\mathrm{m})$ & Cross Section $\left(\mathrm{m}^{2}\right)$ \\
\hline Vent Shafts & 1 & 60 & 0,79 \\
Surge Tank & 4 & 80 & 12,57 \\
\hline
\end{tabular}

Table 4

Geometric model B of underground lower water storage in the shape of tunnels.

\begin{tabular}{llll}
\hline \multicolumn{2}{l}{ GEOMETRIC MODEL B UNDERGROUND LOWER RESERVOIR } \\
\hline TUNNELS NETWORK & & & \\
\hline Tunnels & Cross Section $\left(\mathrm{m}^{2}\right)$ & Length $(\mathrm{m})$ & Slope $(\%)$ \\
Central Tunnel & 30 & 94 & 0 \\
Transversal Tunnels & 30 & 200 & 0 \\
Submergence Tunnel & 30 & 200 & 10 \\
VENTILATION SHAFT AND SURGE TANK & & \\
\hline Shaft & Diameter $(\mathrm{m})$ & Length $(\mathrm{m})$ & Cross Section $\left(\mathrm{m}^{2}\right)$ \\
\hline Vent Shaft & 2 & 60 & 3,14 \\
Surge Tank & 4 & 80 & 12,57 \\
\hline
\end{tabular}

equation is not used (segregated solver), an algorithm to couple pressure and velocity is needed. Instead of the traditional iterative SIMPLE algorithm, the non-iterative predictive-corrective PISO algorithm has been used, because this algorithm was explicitly developed to accelerate unsteady calculations.

The spatial and temporal derivatives of the fluid flow governing equations were calculated by means of a second-order discretization, and for the pressure interpolation the PREssure STaggering Option (PRESTO) scheme has been used instead of the standard one, because it is better suited for the steep pressure gradients of two-phase flows. Variable time stepping was used in order to automatically change the time step when an interface is moving through dense cells or if the interface velocity is high. The variable time step is based on the maximum Courant number near the VOF interface. As VOF models need a single set of scalar equations shared by phases to define turbulence effects, the three equations of the k-epsilon Re-Normalisation Group (RNG) model was selected for both (air and water) phases in this case. This turbulence model has a good accuracy for recirculating and swirling flows. Since the tunnels of the lower reservoir are lined with a concrete ring, the friction head losses are analyzed considering a wall roughness coefficient of $3 \mathrm{~mm}$ in the numerical model.

\subsection{Simulation methodology}

The simulation methodology consists on the analysis of the behavior of the water-air mixture during the filling stage of the lower reservoir. The beginning of the model is a scenario in which the tunnel network is full of air, only with the submergence tunnel filled with water as a resemblance of the real situation. The pressure and velocity of the air will be checked at the outlet of the ventilation shafts that have been modelled in order to check that the water filling process is stable over time. If the numerical model predicts that the existing air provokes significant pressure losses, then this would imply problems in the operation of the turbine, making difficult the discharge towards the lower reservoir. Air pressure and velocity values will also be checked at the intersection between the ventilation shafts and the tunnels, where major instabilities are expected due to the abrupt changes in the tunnel sections.

\section{Results and discussion}

\subsection{Reservoir model $A$}

The process of filling the tunnels was simulated for a time of 204 s. This simulation time has allowed the analysis of the initial transient state during the filling of the lower reservoir, corresponding to nearly a $16 \%$ of the total amount of water that can be stored in the modelled domain. This also assures that all the monitored variables have reached a steady condition until the complete filling of the tunnels (there are no further variations in the form of filling), so no variation in the conditions is foreseen. During the process, the static pressure and the air velocity at the exit of the ventilation shafts were monitored. The results for the joints between the ventilation shafts and the tunnels were also tracked. Finally, the behavior of the mixture inside the tunnels is analyzed, highlighting the static pressure and the velocity of water and air flow.

Initially ( $\mathrm{t}=0 \mathrm{~s}$ ) it will be considered that the tunnels are completely empty. Following, the water is progressively introduced according to the designed flow rates. In Fig. 4 the volume fraction of water in the tunnels is shown for $\mathrm{t}=15.44 \mathrm{~s}$ and $\mathrm{t}=202.34 \mathrm{~s}$. For $\mathrm{t}=202.34 \mathrm{~s}$ it can be seen that the tunnels have already reached an important volume of water. First of all, the results obtained in the outputs of the shafts are analyzed. According to the graph of Fig. 5, the static pressure is very similar for all the shafts in the underground reservoir.

The stability of the process has also been verified, with constant 


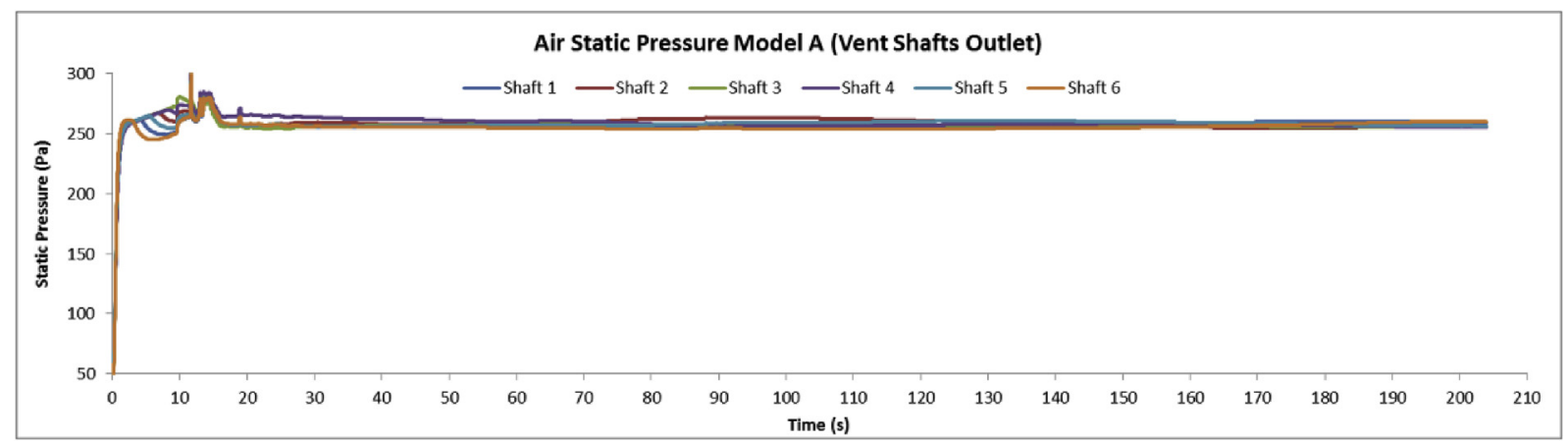

Fig. 5. Evolution of the Static Pressure at the exit of the ventilation shafts during the process of filling the underground reservoir (model A).

pressure values for the entire filling process. At the beginning of the simulation, small pressure variations can be observed between $\mathrm{t}=0$ and $\mathrm{t}=20 \mathrm{~s}$. This is due to the formation of a wave, which dissipates over time until it stabilizes.

The average value of the static pressure has been $258.96 \mathrm{~Pa}$. Regarding the magnitude of the velocity, as indicated in Fig. 6, it is very stable for all the shafts, with an average value of $6.41 \mathrm{~m} / \mathrm{s}$. With these values a dynamic pressure of $24.65 \mathrm{~Pa}$ and a total pressure of 283.61 Pa are obtained.

Regarding the unions of the shafts with the tunnels, due to the pressure loss that it is produced by the passage of the flow through the ventilation duct, the results of static pressure are slightly higher than those obtained in the outputs, with an average value of $312.30 \mathrm{~Pa}$. The filling process is also stable in these areas, as shown in Fig. 7. The velocity is also constant throughout the process, with an average value of $6.81 \mathrm{~m} / \mathrm{s}$. The evolution of the velocity in these sections is shown in Fig. 8. As in the outputs of the shafts, small variations in pressure and velocity occur at the beginning of the filling process, due to the initial wave, which quickly stabilizes.

The maps of results of air velocity and total pressure are shown in Fig. 9 for $\mathrm{t}=202.34 \mathrm{~s}$. Maximum values of $8 \mathrm{~m} / \mathrm{s}$ of air output velocity and $285 \mathrm{~Pa}$ of static pressure have been obtained.

Unlike what happens in the ventilation shafts, where only the air outlet exists, the tunnels exhibit the presence of the two fluids interacting, water and air. In Fig. 10 the evolution of the static pressure inside the tunnels is shown. Until the water reaches the sections of the tunnels that have been studied there is only air, and the average static pressure is around $350 \mathrm{~Pa}$. As the tunnels are filled with water, the value of the static pressure increases due to the specific weight of the water (i.e., hydrostatic pressure). The pressure starts to rise more quickly in tunnel 4, because it is closer to the end of the water course. At the final stages of the simulation $(t=202.34 \mathrm{~s})$, the pressure reaches the average value of $5500 \mathrm{~Pa}$ in tunnel 4.

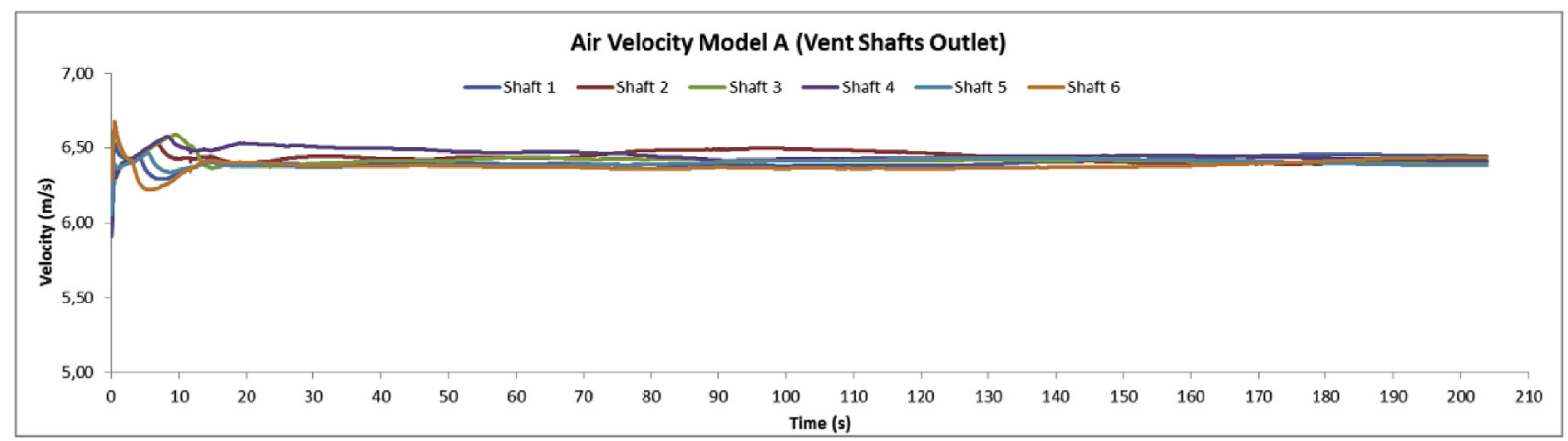

Fig. 6. Evolution of the velocity of the air at the exit of the ventilation shafts during the process of filling the underground reservoir (model A).

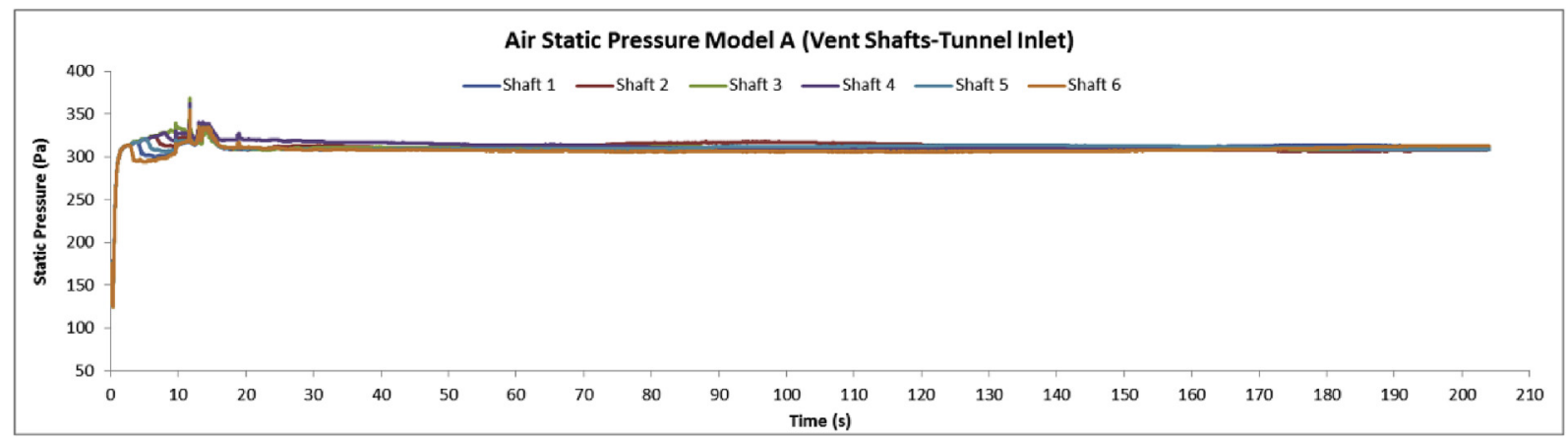

Fig. 7. Evolution of the Static Pressure in the joints of the ventilation shafts and the tunnels during the process of filling the underground reservoir (model A). 


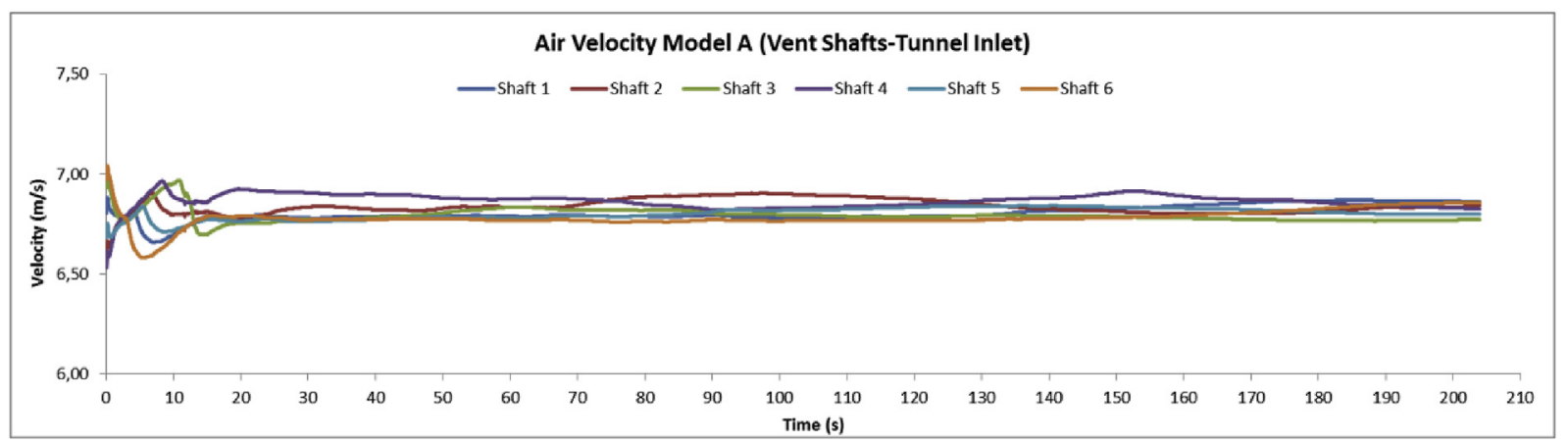

Fig. 8. Evolution of the Static Pressure in the joints of the ventilation shafts and the tunnels during the process of filling the underground reservoir (model A).

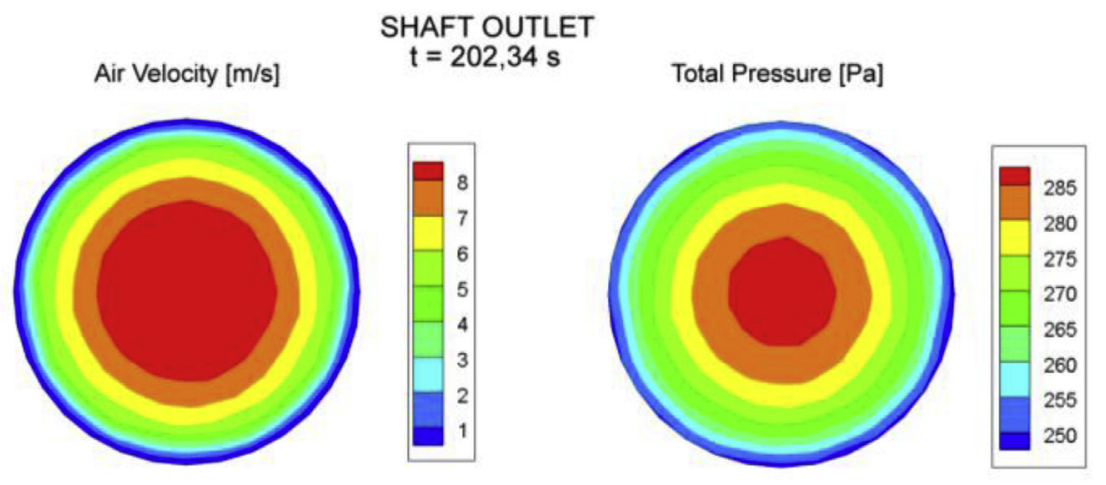

Fig. 9. Air velocity and total pressure shafts outlet $\mathrm{t}=202.34 \mathrm{~s}$.

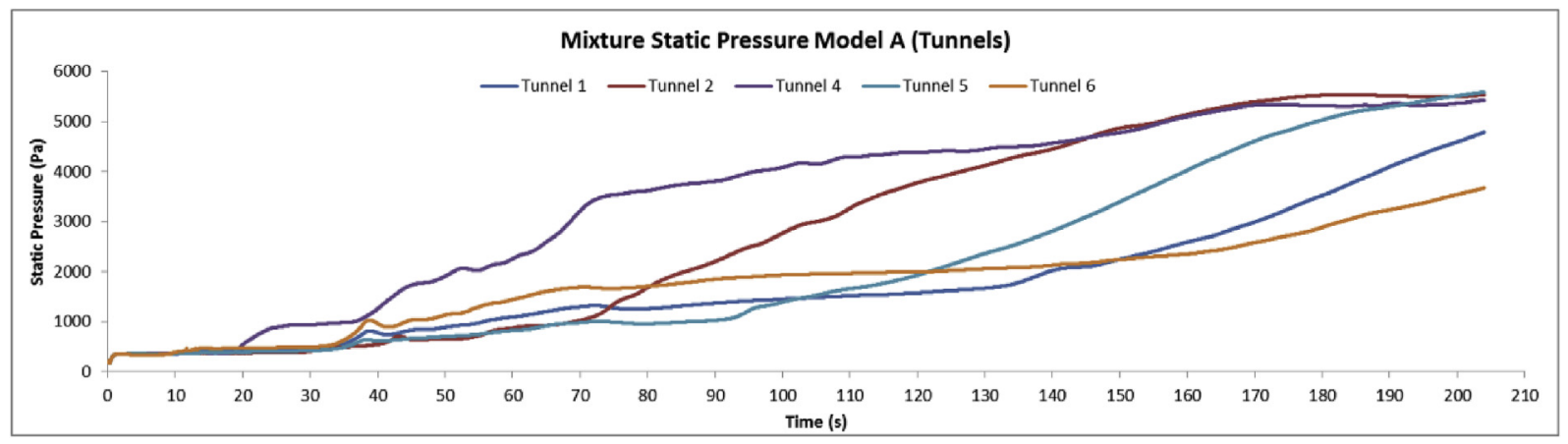

Fig. 10. Evolution of the Static Pressure inside the tunnels during the process of filling the underground reservoir (model A).

Fig. 11 shows the evolution of the velocity of the mixture inside the tunnels. Because it is a section larger than the ventilation shafts, the velocity values are lower. In the initial instants during the filling process, the values are very uniform, in the order of $0.17 \mathrm{~m} / \mathrm{s}$, increasing as the water is flooding the tunnels.

Fig. 12 shows the maps of velocity and static pressure results in the tunnels for $\mathrm{t}=202.34 \mathrm{~s}$. The section indicated in this case is the one corresponding to tunnel 6. As indicated in Fig. 5, the upper part of the maps corresponds to the values relative to the air flow. The maximum values obtained are $2.2 \mathrm{~m} / \mathrm{s}$ of velocity (water flow) and $19,000 \mathrm{~Pa}$ of static pressure. As the filling process is advanced, the static pressure rises due to the increase in hydrostatic pressure. In the case of water velocity, the values are higher in the right part of the section due to the location of this tunnel in the model. The tunnels shown in Fig. 12 correspond to tunnel 6 of the model of Fig. 3. The water flow makes a right turn to fill tunnel 6 , producing an asymmetric velocity map in this section of the lower reservoir. The values obtained for the air are lower than those of the water flow. The water velocity reaches $2.2 \mathrm{~m} / \mathrm{s}$ while the air velocity is between 0.6 and $0.8 \mathrm{~m} / \mathrm{s}$.

\subsection{Reservoir model $B$}

In this case, the filling process was simulated for a time of $203 \mathrm{~s}$. In Fig. 13 the volume fraction of water in the tunnels is shown for $t=31.15 \mathrm{~s}$ and $\mathrm{t}=201.65 \mathrm{~s}$. Because the ventilation shaft has $\mathrm{a}$ larger section than in the case of model $A$, the pressure drop of the circuit is lower. The static pressure at the outlet of the shaft is very low, obtaining an average value of $1.9 \mathrm{~Pa}$, while the total pressure is 55 Pa.

Fig. 14 shows the evolution of the static pressure and the velocity magnitude of the air flow at the exit of the ventilation shaft. 


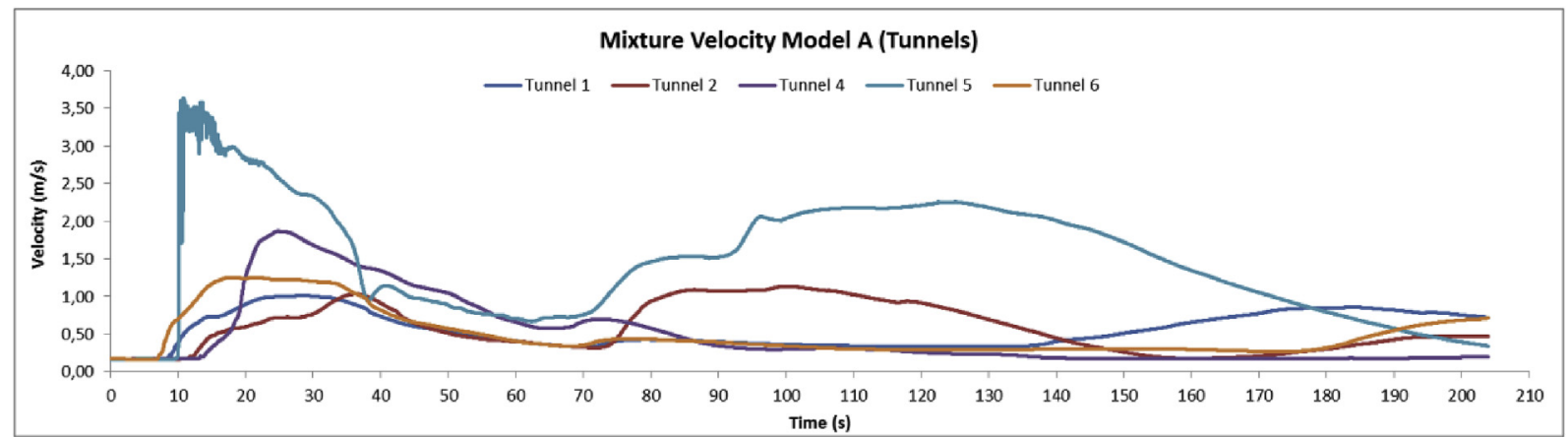

Fig. 11. Evolution of the Velocity Magnitude inside the tunnels during the process of filling the underground reservoir (model A).

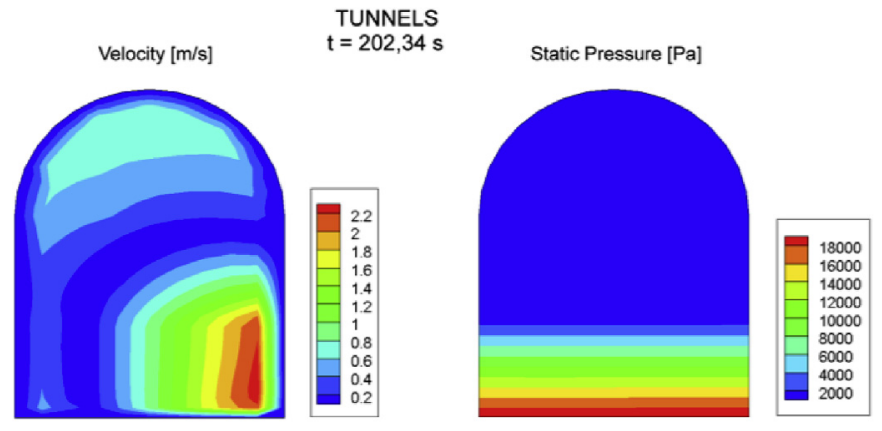

Fig. 12. Velocity and static pressure in tunnels $t=202.34 \mathrm{~s}$.

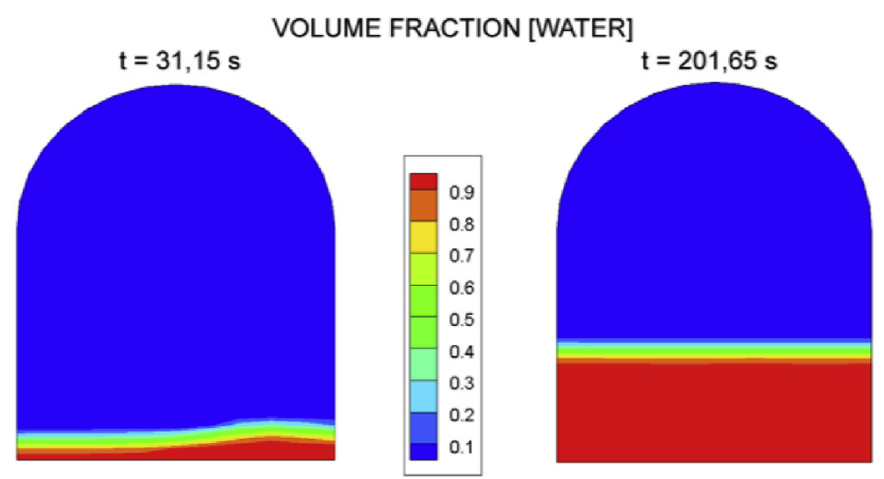

Fig. 13. Volume fraction in tunnels $t=31.15 \mathrm{~s}$ and $\mathrm{t}=201.65 \mathrm{~s}$.

The resistance of the ventilation shafts is inversely proportional to the section. The pressure is very stable throughout the filling process. The velocity at the exit is $9.55 \mathrm{~m} / \mathrm{s}$, and it is also very stable during the process. In this case, the air flow leaves entirely by the only existing shaft, so the air velocity is higher than that obtained in model A.

The evolution of the static pressure and velocity of the air at the junction of the central tunnels and the ventilation shaft is shown in Fig. 15. The values of static pressure are slightly higher than those obtained at the outlet of the shaft, due to the pressure loss produced by friction in the walls of the ventilation shaft. The average value of the static pressure is $57.71 \mathrm{~Pa}$, while the average air velocity is $10.61 \mathrm{~m} / \mathrm{s}$. Both the pressure and air velocity are very stable during the filling process of model $\mathrm{B}$ of the lower reservoir.

The maps of results of air velocity and total pressure are shown in Fig. 16 for $t=201.65 \mathrm{~s}$. Maximum values of $11 \mathrm{~m} / \mathrm{s}$ of air output velocity and $80 \mathrm{~Pa}$ of static pressure have been obtained.

In the same way as previous model $A$, the tunnels increase the static pressure as the water level is increased. In model B, as shown in Fig. 17, the air pressure at the beginning of the process is lower than model $\mathrm{A}$, with an average value of $150 \mathrm{~Pa}$, while in model $\mathrm{A}$, it is $350 \mathrm{~Pa}$. If the filling process of both models is compared, it can be concluded that they are very similar, with a lower pressure in model B.

Regarding the velocity of the flow inside the tunnels, at the beginning of the process, as there are no ventilation shafts, there is no air circulation, with a result of zero velocity, as it can be seen in Fig. 18. When the water enters the transverse tunnels, it increases the velocity of the flow, leaving all the air through the ventilation shaft. Fig. 19 shows the maps of velocity and static pressure results in the tunnels. Fig. 19a shows the speed of the water and air inside the tunnels, where water and air move in the same direction. The lower part of the tunnel corresponds to the filling of the water and the velocity of this fluid is higher than the air velocity, which circulates in the upper area of the tunnels. Fig. 19b represents the static pressure in the tunnels. At the time studied a maximum pressure of $16,000 \mathrm{~Pa}$ is reached on the floor of the tunnel.

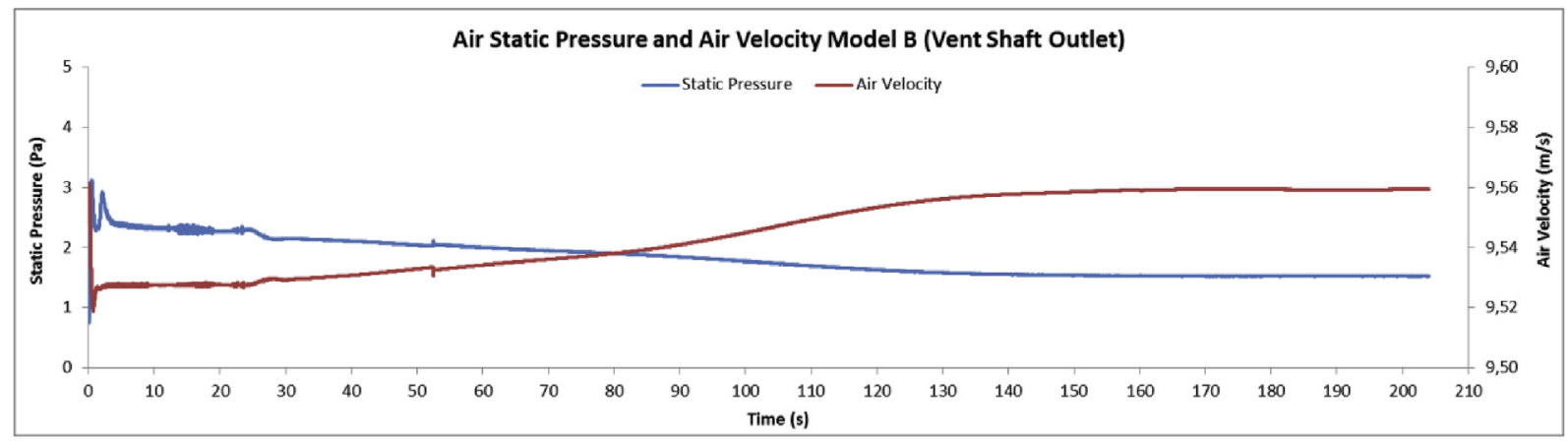

Fig. 14. Evolution of the Static Pressure and Velocity at the exit of the ventilation shafts during the process of filling the underground reservoir (model B). 


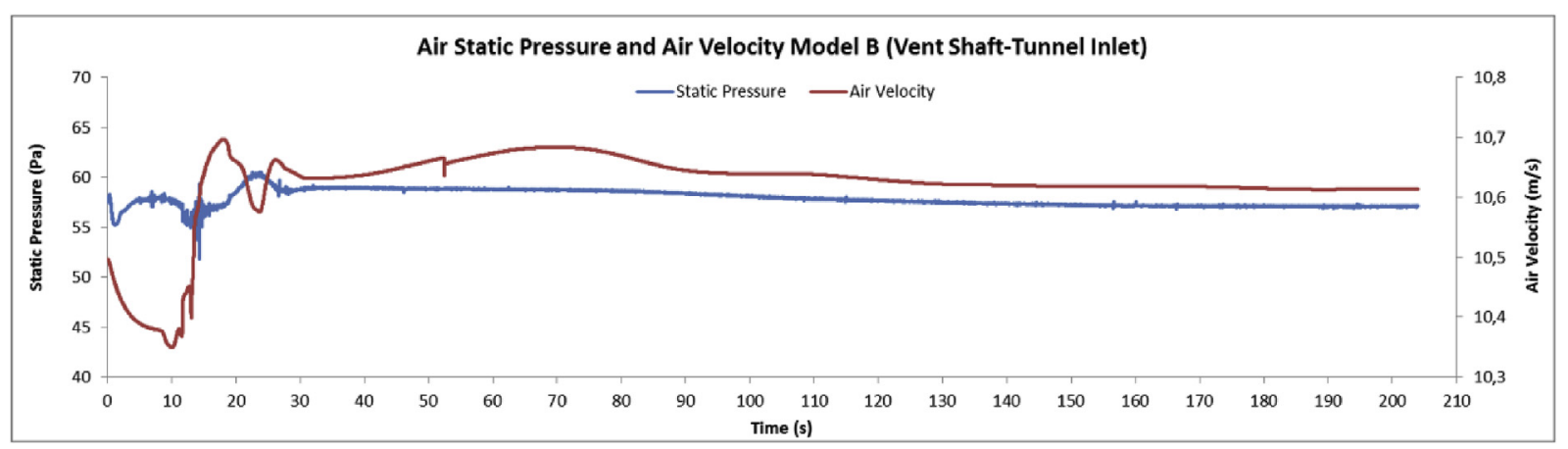

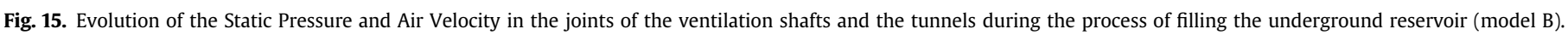

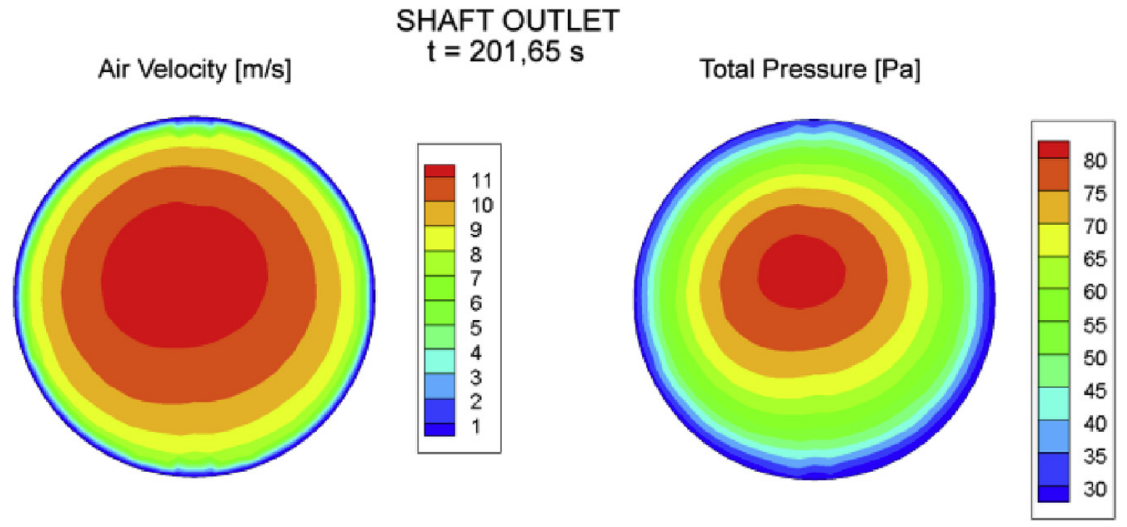

Fig. 16. Air velocity and total pressure shafts outlet $t=201.65 \mathrm{~s}$.

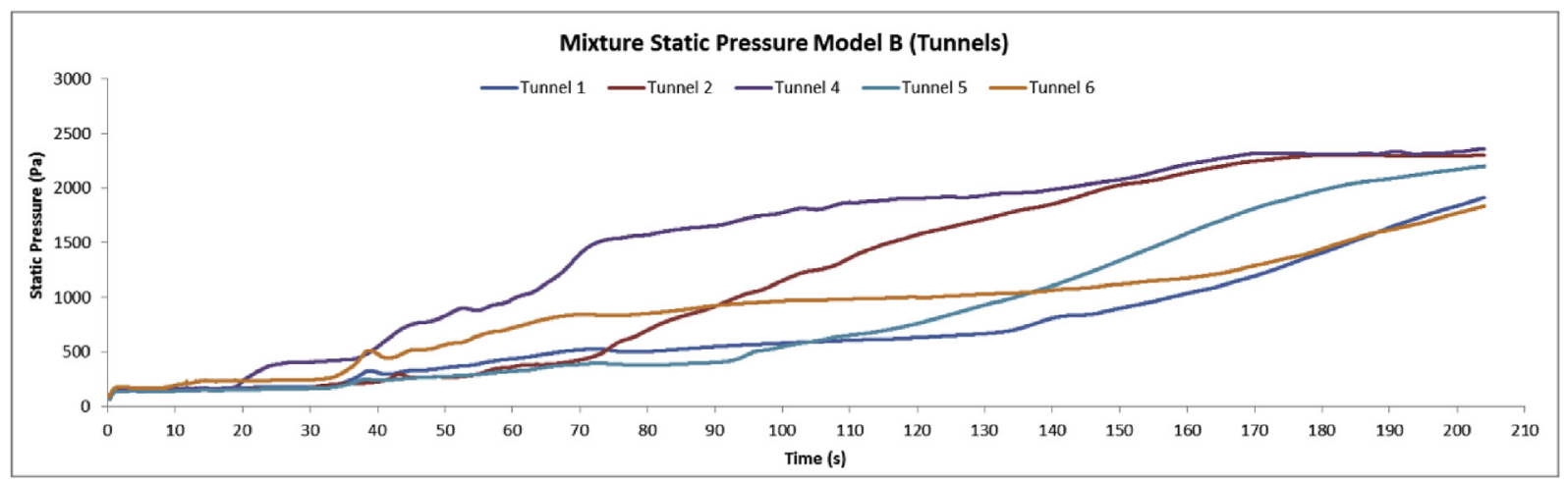

Fig. 17. Evolution of the Static Pressure inside the tunnels during the process of filling the underground reservoir (model B).

\section{Conclusions}

The construction of UPSH plants requires the use of a lower underground reservoir in the form of tunnels. This could lead to problems in the discharge of water from the turbine due to the resistance implied by the lower reservoir, since it is not at atmospheric pressure. This resistance, in case of being high, could require a higher pressure for the turbine to complete the filling of the tunnels network. To reduce this resistance, the role of ventilation shafts is fundamental. To analyze the resistance of the tunnel network, two reservoir models have been designed. Model A that has a ventilation shaft at the end of each tunnel, and model B, which has a single ventilation shaft at the end of the central tunnel, with a section superior to the previous ones.
In model $A$, the pressures of air output at the ventilation shafts and the pressures inside the tunnels are higher than in model B. The resistance of model $\mathrm{B}$ for the filling process is lower, although it only has one outlet for air. After the studies that have been carried out for both reservoirs, it can be concluded that the filling processes of the tunnels are very stable over time, with moderate static pressure values, below $350 \mathrm{~Pa}$. This means that there would be no problems in the discharge, ensuring the correct operation of the turbines. Although the filling efficiency is $100 \%$ in both models, model B seems more appropriate because it assumes lower investment costs than model $A$. The cessation of the extractive activity of coal by means of underground mining in the ACCB implies the loss of an important economic activity in the mining regions. The use of underground mining for the construction of UPSH plants 


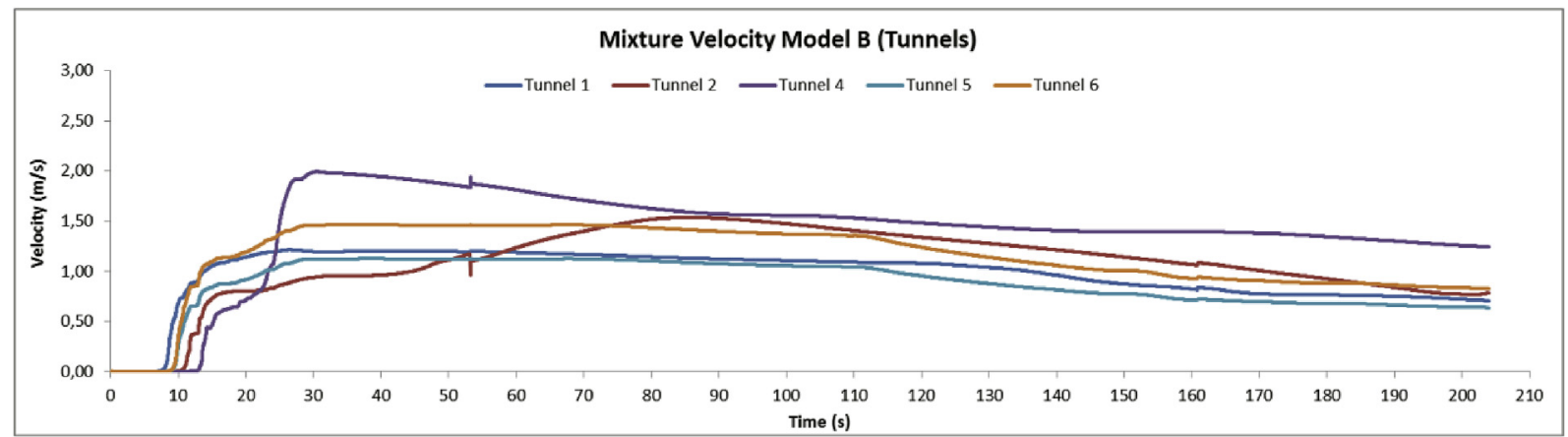

Fig. 18. Evolution of the Velocity Magnitude inside the tunnels during the process of filling the underground reservoir (model B).

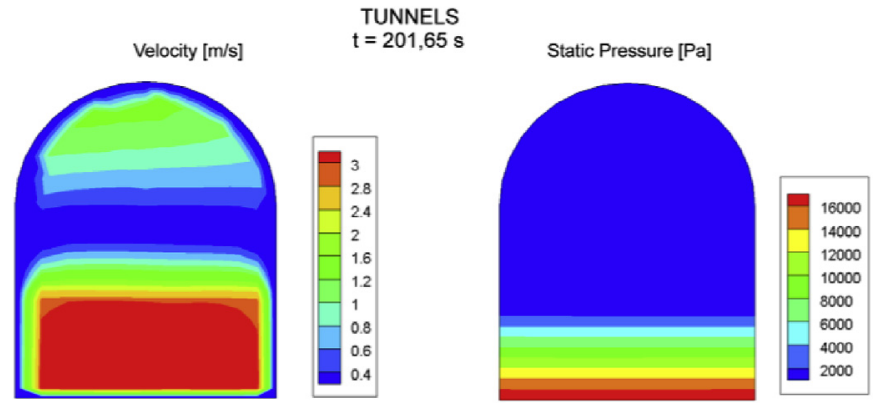

Fig. 19. Velocity and static pressure in tunnels $\mathrm{t}=201.65 \mathrm{~s}$.

could lead to the creation of an important source of employment and wealth generation in the mining regions, affected by the closure of the mines. In addition, unlike conventional projects, when using underground mining coal mines there are no negative impacts on the environment, which makes it one of the main advantages.

From these facilities it is possible to produce and consume significant amounts of energy that could be used to adjust the electricity system due to the increase in the share of renewable energy in the electricity mix. A high component of this mix will be nondispatchable renewable sources such as wind and solar, so it will be necessary to build energy storage systems to adjust the production of electricity to the demand curve at all times.

\section{References}

[1] International Energy Agency (IEA). Key World Energy Trends, except from: Renewables Information.

[2] European Council, Presidency Conclusions to the European Council of 29/30 October 2009, European Council, Brussels, 2009.

[3] EC, Communication from the Commission to the European Parliament, the Council, the European Economic and Social Committee and the Committee of the Regions. An Energy Policy for Europe (COM/2007/1 Final), European Commission, Brussels, 2007.

[4] Y. Hu, Z. Bie, T. Ding, Y. Lin, An NSGA-II based multi-objective optimization for combined gas and electricity network expansion planning, Appl. Energy 167 (2016) 280-293.

[5] A. Mileva, J. Johnston, J.H. Nelson, D.M. Kammen, Power system balancing for deep decarbonization of the electricity sector, Appl. Energy 162 (2016) $1001-1009$.

[6] T. Okazaki, Y. Shirai, T. Nakamura, Concept study of wind power utilizing direct thermal energy conversion and thermal energy storage, Renew. Energy 83 (2015) 332-338.

[7] C. Bussar, P. Stöcker, Z. Cai, L. Moraes Jr., D. Magnor, P. Wiernes, N. van Bracht, A. Moser, D.U. Sauer, Large-scale integration of renewable energies and impact on storage demand in a European renewable power system of 2050 sensitivity study, J. Energy Storage 6 (2016) 1-10.

[8] P. Moriarty, D. Honnery, Can renewable energy power the future? Energy Pol. 93 (2016) 3-7. https://doi.org/10.1016/j.enpol.2016.02.051.

[9] M. Delfanti, D. Falabretti, M. Merlo, Energy storage for PV power plant dispatching, Renew. Energy 80 (2015) 61-72.

[10] J.P. Deane, B.P. Ó Gallachóir, E.J. McKeogh, Techno-economic review of existing and new pumped hydro energy storage plant, Renew. Sust. Energ. Rev. 14 (2010) 1293-1302.

[11] B. Steffen, Prospects for pumped-hydro storage in Germany, Energy Pol. 45 (2012) 420-429.

[12] IEA. U.S. Energy Information Administration: International Energy Statistics. https://www.iea.org/.

[13] International Renewable Energy Agency, Renewables and Electricity Storage: a Technology Roadmap for Remap 2030, June, 2015. https://www.irena.org DocumentDownloads/Publications/IRENA_REmap_Electricity_Storage_2015. pdf.

[14] I.H. Wong, An underground pumped storage scheme in the bukitTimah granite of Singapore, Tunn. Undergr. Space Technol. 11 (4) (1996) 485-489.

[15] S. Kucukali, Finding the most suitable existing hydropower reservoirs for the development of pumped-storage schemes: an integrated approach, Renew. Sustain. Energy Rev. 37 (2014) 502-508.

[16] R. Madlener, J.M. Specht, An Exploratory Economic Analysis of Underground Pumped-storage Hydro Power Plants in Abandoned Coal Mines, FCN, 2013. Working Paper No. 2/2013.

[17] A. Zillmann, E. Perau, A conceptual analysis for an underground pumped storage plant in rock mass of the Ruhr Region, Proceedings of the XVI, in: European Conference on Soil Mechanics and Geotechnical Engineering (ECSMGE), 13.-17.09.2015, ICE Publishing, Edinburgh, 2015, pp. 3789-3794 https://doi.org/10.1680/ecsmge.60678.

[18] R. Alvarado, A. Niemann, T. Wortberg, Underground pumped-storage hydroelectricity using existing coal mining infrastructure, in: E-proceedings of the 36th IAHR World Congress, 28 June-3 July, 2015, 2015 the Netherlands: The Hague.

[19] E. Pujades, P. Orban, S. Bodeux, P. Archambeau, E. Erpicum, A. Dassargues Underground pumped storage hydropower plants using open pit mines: how do groundwater exchanges influence the efficiency? Appl. Energy 135 (2016) 146-190.

[20] Fessenden RA. reportSystem of Storing Power, Application Filed June 7, 1907 : 1,247,520 Patented Nov. 20, vol. 191, 7, 1917.

[21] R.D. Harza, Hydro and pumped storage for peaking, Power Eng. 64 (10) (1960) $79-82$.

[22] G. Isaaksson, D. Nilsson, T. Sjostrand, Pumped Storage Power Plants with Underground Lower Reservoirs. Seventh World Power Conference, Section 2 1968. Paper 160, Moscow.

[23] K.E. Sorensen, Underground reservoirs: pumped storage of the future? Civ. Eng. 39 (3) (1969) 66.

[24] Dames, Moore, An assessment of hydroelectric pumped storage, Nat. Hydroelectr. Power Res. Study X (1981) 517. Under contract No. DACW-31-80 C0090 to US Army Corps of Engineers.

[25] S.W. Tam, C.A. Blomquist, G.T. Kartsounes, Underground pumped hydro storage - An overview, in: First Annual Conference on Mechanical and Magnetic Energy Storage Contractors' Information-exchange, Luray, Virginia October 24-26, 1978.

[26] K.B. Braat, H.P.S. Van Lohuizen, JF. De Haan, Underground pumped hydrostorage project for The Netherlands, Tunnel. Tunnel. 17 (11) (1985) 19-22.

[27] A. Niemann, MachbarkeitsstudiezurNutzung von Anlagen des SteinkohlebergbausalsPumpspeicherwerke, in: Conference talk held at: PumpspeicherkraftwerkeunterTage: Chance für das Ruhrgebiet, 2011-11-Essen, Germany, 2011. www.uni-due.de/wasserbau.

[28] Beck HP, Schmidt M, editors. WindenergiespeicherungdurchNachnutzungstillgelegterBergwerke.

[29] H. Luick, A. Niemann, E. Perau, U. Schreiber, Coalmines as underground pumped storage power plants (UPP) - a contribution to a sustainable energy supply? Geophys. Res. Abstr. 14 (2012) 4205.

[30] J. Alterach, G. Bruno, A. Danelli, P. Federici, G. Costantino, Calcolo del potenziale di accumuloenergetico mediante impianti di pompaggioidroelettricosotterraneo, 2016. RSE Ricerca di Sistema reportprot. 16002842, Feb 29th.

[31] European Council. Council Decision of 10 December 2010 on State aid to 
facilitate the closure of uncompetitive coal mines (2010/787/EU). http://data europa.eu/eli/dec/2010/787/oj.

[32] M.P. Henton, The problem of water table rebound alter mining activity and its effects on ground and surface water quality, in: W. van Duijvenbooden, P. Glasbergen, H. Van Lelyveld (Eds.), Quality of Groundwater, Proceedings of the International Symposium Noordwijkerhout, Elsevier, The Netherlands, 1981, pp. 111-116.

[33] L. Kortas, P.L. Younger, Using the GRAM model to reconstruct the important factors in historic groundwater rebound in part of the Durham Coalfield, UK, Mine Water Environ. 26 (2007) 60-69.
[34] P.L. Younger, S.A. Banwart, R.S. Hedin, Mine Water. Hydrology, Pollution, Remediation, Kluwer Academic Publishers, Dordrecht, The Netherlands, 2002.

[35] E. Pummer, H. Schüttrumpf, Reflection phenomena in underground pumped storage reservoirs, Water 10 (2018) 504-516.

[36] C. Hirt, B. Nichols, Volume of fluid (VOF) method for the dynamics of free boundaries, J. Comput. Phys. 39 (1981) 201-225. https://doi.org/10.1016/ 0021- 9991(81)90145-5.

[37] D. Youngs, Time-dependent multi-material flow with large fluid distortion, in: K.W. Morton, M.J. Baines (Eds.), Numer Methods Fluid Dyn, Academic Press, New York, 1982, pp. 273-285. 